\title{
Individuals' Knowledge, Beliefs, Attitudes, and Behaviors toward Animal Releasing
}

\author{
Jeaw-Mei Chen', Mei-Long Lin'2, Mein-Woei Suen3,4,5* \\ ${ }^{1}$ Examination Yuan, Taiwan \\ ${ }^{2}$ Department of Applied English, Jinwen University of Science and Technology, Taiwan \\ ${ }^{3}$ School of Psychology and Institute of Clinical Psychology, Chung Shan Medical University, Taiwan \\ ${ }^{4}$ Chung Shan Medical University Hospital, Taiwan \\ ${ }^{5}$ Social and Gender Issue Research Center, Chung Shan Medical University Hospital, Taiwan \\ Email: ${ }^{*}$ blake5477@yahoo.com.tw
}

Received 6 July 2014; revised 11 August 2014; accepted 28 August 2014

Copyright (C 2014 by authors and Scientific Research Publishing Inc.

This work is licensed under the Creative Commons Attribution International License (CC BY). http://creativecommons.org/licenses/by/4.0/

(c) () Open Access

\begin{abstract}
The aim of this study was to propose and validate "a great variety of animals may be released" and "attitudes toward animal releasing". To achieve this goal, the self-developed Likert-typed questionnaire and demographic data were adapted. The demographic data collected from both stages were analyzed. Only the beliefs, knowledge, attitudes, and behaviors of the participants from the first stage were examined. Regression and path analysis were done for the data from both stages. The questionnaire research was divided into two stages. At the first stage, the questionnaire was answered by people from schools or private businesses in the northern, middle, and southern parts of Taiwan. A total of 1225 valid questionnaires were collected, among which only $9.3 \%$ of the participants were found to have ever joined animal releasing activities. At the second stage, the participants were chosen from the religious groups in northern Taiwan that offered animal releasing activities. A total of 151 valid questionnaires were collected. By the regression analysis of demographic data and beliefs of animal releasing, the result shows that "the experience of participating in religious ceremony to be one of the groups" is the strongest predictor; the "participants gender" and "their mother's religions" influence knowledge of animal releasing most. The beliefs of animal releasing can account for much of attitudes than knowledge variables can do. "Beliefs of animal releasing" is more important than "significant others' support" and "significant others' support" is more important than "knowledge of animal releasing." The main findings of the correlation among beliefs, knowledge, attitudes, and behaviors of animal releasing include the following: 1) through attitude, beliefs mediate behaviors; 2) through attitude, knowledge mediate behaviors; 3) knowledge influences behaviors directly; 4) attitude influences behaviors directly.
\end{abstract}

"Corresponding author. 


\section{Keywords}

\section{Animal Releasing Belief, Animal Releasing Knowledge, Animal Releasing Attitude, Animal Releasing Behavior, Religious Group}

\section{Introduction}

Animal releasing is a popular activity in Taiwan that involves a huge amount of money and a large number of people and animals. In terms of species, a great variety of animals may be released, especially the bird and the fish. In addition, in terms of number, an estimated 200 million animals are released by temples across Taiwan every year. But, why do people release animals?

This study points out two reasons why people release animals: 1) in the Chinese culture, many people believe that animal releasing helps them or their family member live longer, overcome difficulties, avoid danger, cure disease, escape misfortune, and improve destiny; 2) some people, most importantly, even believe that more animals they release, the more blessings they will have.

However, what does the animal releasing mean? Whether it is "saving" or "killing" animals while they have been released. Because of the inadequate knowledge of ecology and the nature of animal released, animal releasing often causes foreign species to invade, food chains to be broken, hybrids to appear, genes to change, and thus bring severe impact on the ecology of Taiwan.

To meet the demand for releasing, the abusive capture by the suppliers causes the wildlife to die massively and even to become reproduction rapidly. Sometimes a "capture and releasing species" appears, in which people capture the animals released earlier and sell them again for releasing — an act of cheating on people and "second harm" to animals.

\section{Purpose}

Animal releasing is an act of good intention, but improper way of doing it will damage our ecological system. In an attempt to change improper animal releasing, this study should first understand people's concepts, and idea, of animal releasing.

According to the Ajzen and Feshbein's $(1975,1980)$ Rational Behavior Theory (as the function shown next), Behavior is affected by behavior intention, and behavior intention is determined by attitude toward the action, normative belief and perceived personal contrast where, the function showed as below (Zafirovski, 2003).

$$
A_{\text {beh }}=\sum_{i=1}^{n} B_{i} a_{i}
$$

$A_{\text {beh }}$ : Attitude or intention of acting a certain behavior.

$B_{i}$ : The possibility of behavior leads the results.

$a_{i}$ : Personal evaluation of the results.

So, do people release animals because they behavior that releasing animals can bring them some advantages, because they believe that their significant others expect them to do so? And/or because they believe that they can do it easily?

Other theories of attitude change and persuasion such as Elaboration Likelihood Model and Heuristic System Model also emphasize the role of cognition in attitude change (Chaiken, 1980; Chaiken \& Maheswaran, 1994), thus the first focus of present study is the beliefs related to animal releasing, mainly the perception of the outcome of animal releasing (Chaiken, 1987; Petty \& Cacioppo, 1986).

Thus, in order to understand the factors of release animals, following paragraphs are going to identified "knowledge”, "beliefs”, “attitude”, and "behavior”.

\section{Researches Related to the Understanding of Animal Releasing}

In general, beliefs mean the concept toward the certain targets. In addition, Attitude actually means a positive, negative, or mixed reaction to a person, object, or idea and it is not only an important issue in social psychology, 
but also an important predictor of people's behavior. However, in the animal releasing studies this study has not found any research focusing on this concept yet. This study takes attitudes toward animal releasing as the core concept. Therefore, items such as "I feel that animal releasing is good" and "People who do not support animal releasing lack of compassion” were collected to be included into the Liker attitude scale through item analysis to measure the extent to which people support animal releasing.

Knowledge means the related knowledge of animal releasing and it may also be an important factor in determining whether a person will participate in animal releasing (i.e. related behavior of animal releasing). For example, if people are told that " $90 \%$ of the released animals will die" or "the amount of money that people donate to animal releasing activities in Taiwan can offer lunch to 20 thousand students from poor families for one year", they may give up participating in animal releasing activities. Because few empirical studies have been done, the present study consults experts in the released field for the knowledge of animal releasing to develop an appropriate questionnaire.

In the result variables (see Figure 1), this study examined whether the interviewees had ever participated in animal releasing activity, their reasons, ways, frequencies, (start continue, or stop) to take part in animal releasing.

\section{Methodology}

This study measured people's beliefs, knowledge, attitudes, and behaviors toward animal releasing by our questionnaires. To measure beliefs of and attitudes toward animal releasing, the study evaluated participant's level of agreement on qualities related to animal releasing according to their perception, feeling and experience. To measure how much people know about animal releasing, this study measured the relevant facts and level of knowledge of animal releasing. To understand people's behavior, this study measured the participant's experiences of animal releasing. The participants' demographic data was also collected.

\subsection{Materials}

Self-Developed Likert-Typed Questionnaires: the questionnaires based on the integration of theoretical construct and results of factor analysis. Each questionnaire can further divided into several sub-dimension.

\subsubsection{Animal Releasing Belief Questionnaire}

- Influence of animal releasing on the actor.

- Influence of animal releasing on others (or society).

- Influence of animal releasing on the animal released.

- Influence of animal releasing on the ecosystem and environment.

- The degree to which people trust the animal releasing group.

- The perspectives on animal rights.

- The substitution and revised method for releasing animal.

- The feelings of common fate.

\subsubsection{Animal Releasing "Knowledge" Questionnaire}

- Influence of animal releasing on the ecosystem and environment.

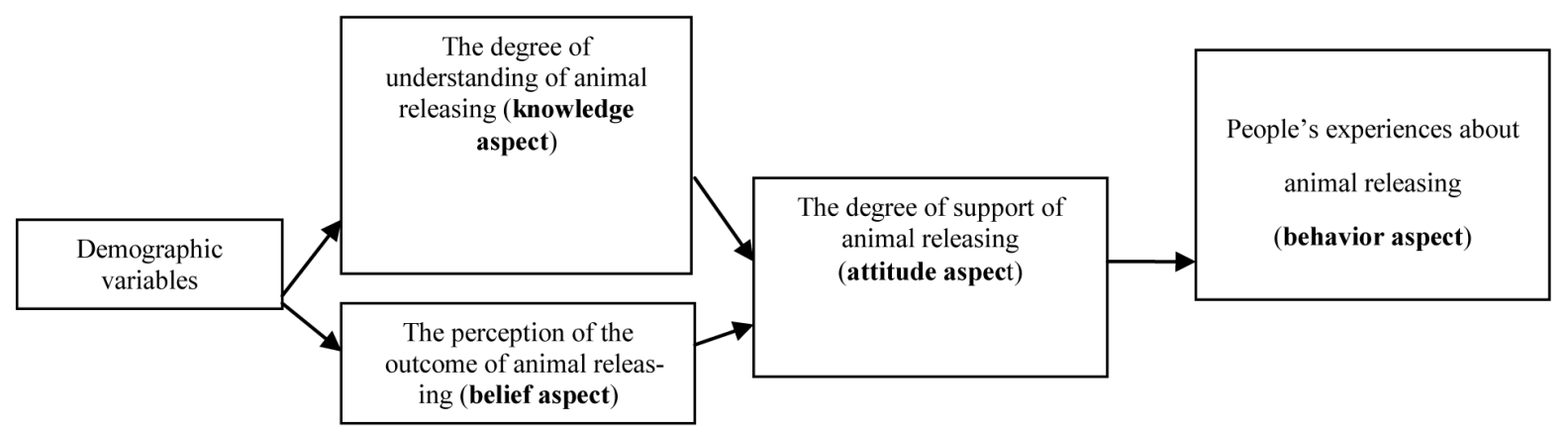

Figure 1. Research framework. 
- Laws and regulations related to animal releasing.

- Status quo and fact of animal releasing.

\subsubsection{Animal Releasing "Attitude" Questionnaire}

- Pro-animal releasing questions.

- Anti-animal releasing questions.

\subsubsection{Animal Releasing "Behavior" Questionnaire}

Ten questions: including animal releasing experience, their reasons, ways, and frequencies of participation etc.

\subsubsection{Demographic Information}

In this study, demographic data include 16 questions: e.g. including age, education, income, occupation, residency, marital status, religion etc.

\subsection{Participants}

The data collection was divided into two stages. At the first stage, the questionnaire was answered by parents of school children or employees of private business sectors in the northern, middle, and southern parts of Taiwan. A total of 1225 valid questionnaires were collected, among which only $9.3 \%$ of the respondents had ever personally participated in animal releasing activities.

At the second stage, the participants were recruited from the religious groups in northern Taiwan that offered animal releasing activities. A total of 151 valid data were collected.

\subsection{Analysis}

The demographic data collected from both stages were analyzed. The knowledge, of the participants from only the first stage was examined. Regression and path analysis were done for the date from both stages.

\section{Results}

\subsection{Beliefs about Animal Releasing}

After integrating the researcher's concepts and results from the factor analysis, this study found eight subdimensions of the beliefs about animal releasing. In general, people’ beliefs about animal releasing are slightly negative $(M=2.93)$, indicating that people do not have very positive belief of animal releasing.

Among the 8 sub-dimensions, people has positive belief on only 3 of them: the perspective of animal rights, the feelings of common fate, and the degree to which people trust the animal releasing groups. Respondents have most negative belief on: "the influence of animal releasing on the ecosystem and environment." Among the sub-dimensions, people have positive belief on only 3 of them.

In general, people' beliefs about animal releasing are slightly negative $(M=2.93)$, indicating that people do not have very positive belief of animal releasing.

\subsection{Knowledge of Animal Releasing}

\subsubsection{It Can Be Divided into Three Aspects}

- The influence of animal releasing on the ecosystem and environment.

- Laws and regulations related to animal releasing.

- The status quo and fact of animal releasing.

\subsubsection{People Understand "the Influence of Animal Releasing on the Ecosystem and Environment" the Most \\ Based on the percentage of "knowing": \\ - "Influence of animal releasing on the ecosystem and environment” (73.79\%) ranks the first. \\ - "Status quo and fact of animal releasing” (43.18\%) the second. \\ - "Laws and regulations related to animal releasing” (12.27\%) the third.}


Based on the percentage of "accuracy":

- "Influence of animal releasing on the ecosystem and environment" (88.47\%) ranks the first.

- "Laws and regulations related to animal releasing" (77.93\%) the third.

- "Status quo and fact of animal releasing” (75.60\%) the second.

\subsection{Attitudes toward Animal Releasing}

Participants' average score on "attitude toward animal releasing" scale is 2.8 , indicating that they slightly do not support this activity. The average score of pro-items is 2.64 and the average score of anti-items is 2.98 . Participants do not consider animal releasing a good deed.

\subsection{Regression Analysis}

\subsubsection{The Influence of Demographic Variables}

In the regression analysis of demographic data on beliefs of animal releasing, the result show that "ritualized behavior" is the strongest predictor. In the regression analysis of demographic data on knowledge of animal releasing, the finding indicates that all variable are weak predictors. In the regression analysis of demographic data on attitudes toward animal releasing, the results show that "ritualized behavior," "monthly income" and "education" are most influential predictors. "Ritualized behavior" can also explain significant amount of the animal releasing behavior.

\subsubsection{Behavior about Animal Releasing}

The result shows that only 115 of the 1225 participants have direct experience of animal releasing, indicting that most people do not have chance to be involved in large animal releasing activities.

\subsubsection{The Reasons for That}

- They never have access to this information.

- They would rather donate something directly to the poor than release animal.

- They worry that these activities will damage the environment.

\subsubsection{Among the Few People Who Have Participated in Animal Releasing, the Reasons for Their} First Participation Were

- They want to benevolent.

- They receive invitation from relatives.

- They want to prey for themselves or others.

\subsubsection{Behaviors People Intend to Do}

- Advocate accurate knowledge about animal releasing.

- Call for proper regulations on animal releasing.

- Use the donation money to set up an animal protection area.

- To establish a foundation to educate people not catching, eating, and killing animals.

\subsection{Regression Analysis}

\subsubsection{The Influence of Demographic Variables}

In the regression analysis of demographic data on beliefs of animal releasing, the result shows that "ritualized behavior" is the strongest predictor. In the regression analysis of demographic data on knowledge of animal releasing, the finding indicates that all variable are weak predictors. In the regression analysis of demographic data on attitudes toward animal releasing, the results show that "ritualized behavior," "monthly income" and "education" are most influential predictors. "Ritualized behavior" can also explain significant amount of the animal releasing behavior.

\subsubsection{Summary of the Regression Analysis on Animal Releasing Attitude}

- The "belief" of animal releasing can account for the "attitude" of animal releasing significantly more than 
the "knowledge" of animal releasing.

- "Beliefs of animal releasing” is more important than "significant others' support" and "significant others' support" is more important than "knowledge of animal releasing" in predicting attitude of animal releasing.

\subsubsection{Summary of Regression Analysis on Animal Releasing Behavior}

The Relationship among Beliefs, Knowledge, and Behavior of Animal Releasing: In general, the sub-dimension 3 of belief questionnaire: "influence of animal releasing in the animals" can explain the variance of animal releasing behaviors the most. The relationship between attitude toward and behavior of animal releasing: The more positive attitude the participants have, the more frequent is the animal releasing behavior.

\subsection{Path Analysis}

The results of the path analysis generally support the research framework of this study. The important findings include: (see the Figure 2).

- The mediating effect of attitude between belief and behavior.

- The mediating effect of attitude between knowledge and behavior.

- The direct effect of attitude on behavior.

- The direct effect of knowledge on behavior.

The "monthly income" and "ritualized behavior" are the most important demographic variables to influence beliefs of animal releasing.

- The more income the participants earned monthly, the less they support animal releasing.

- On the other hand, the people participated in religion activities, the more they support animal releasing.

Participants' monthly income also influence attitude toward animal releasing directly. The "participants' gender" and "their mother's religions" influence knowledge of animal releasing the most. The female participant whose mother holds religion beliefs have more knowledge about animal releasing.

\section{Application and Suggestion}

Based on the present research findings, the knowledge of animal releasing has to be provided the beliefs of animal releasing must be changed, and the attitudes toward animal releasing must be emphasized.

\subsection{Beliefs of Animal Releasing}

In this aspect, it is important to change people's belief “influence of animal releasing on the actor," "influence of

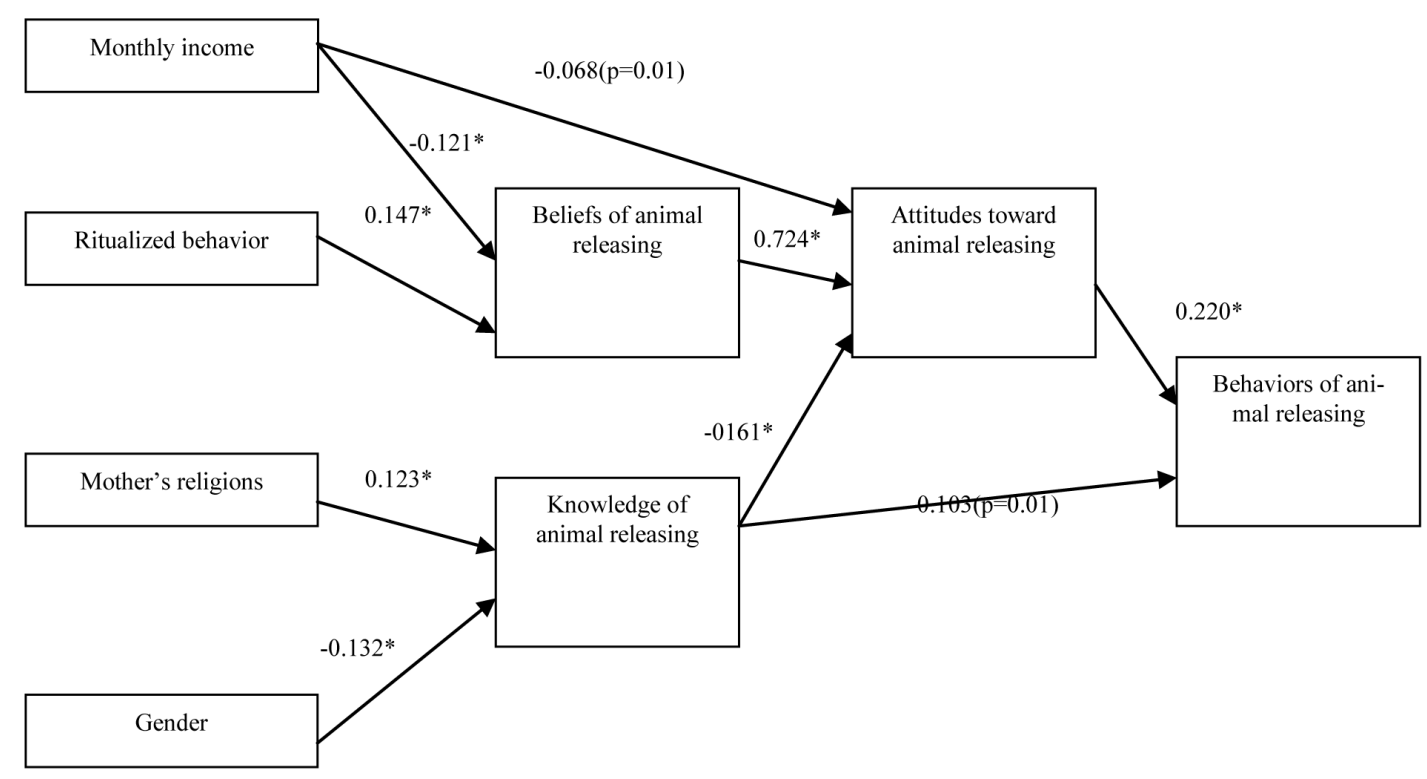

Figure 2. Path analysis of knowledge of animal releasing. 
animal releasing on the animals released," and "the substitution and revised method to release animals". The participants with more positive attitudes are more likely to release animals.

\subsection{Knowledge of Animal Releasing}

On the "knowledge" questionnaire, average percentage of "knowledge" is only $48.2 \%$. It indicates that people do not have enough knowledge of animal releasing and people should be provided related information or educated more. In addition, the results of the "laws and regulations related to animal releasing" reveal that it is the most needed sub-dimension in animal releasing.

Knowledge and beliefs also influence behaviors through attitude. Thus, in addition to increasing knowledge, and changing attitude through changing beliefs, any other factors that may help to change attitude, for example, through affection, authority, or personal experience, are all possible topics for further exploration.

\section{References}

Ajzen, I., \& Fishbein, M. (1975). Belief, Attitude, Intention, and Behavior: An Introduction to Theory and Research. Reading, MA: Addison-Wesley.

Ajzen, I., \& Fishbein, M. (1980). Understanding Attitudes and Predicting Social Behavior. Englewood Cliffs, NJ: PrenticeHall.

Chaiken, S. (1980). Heuristic versus Systematic Information Processing and the Use of Source versus Message Cues in Persuasion. Journal of Personality and Social Psychology, 39, 752-766. http://dx.doi.org/10.1037/0022-3514.39.5.752

Chaiken, S. (1987). The Heuristic Model of Persuasion. In M. P. Zanna, J. M. Olson, \& C. P. Herman (Eds.), Social Influence: The Ontario Symposium (Vol. 5, pp. 3-39). Hillsdale, NJ: Erlbaum.

Chaiken, S., \& Maheswaran, D. (1994). Heuristic Processing Can Bias Systematic Processing: Effects of Source Credibility, Argument, Ambiguity, and Task Importance on Attitude Judgment. Journal of Personality and Social Psychology, 66, 460-473. http://dx.doi.org/10.1037/0022-3514.66.3.460

Petty, R. E., \& Cacioppo, J. T. (1986). Communication and Persuasion: Central and Peripheral Routes to Attitude Change. New York: Spring-Verlag. http://dx.doi.org/10.1007/978-1-4612-4964-1

Zafirovski, M. (2003). Human Rational Behavior and Economic Rationality. Electronic Journal of Sociology. 
Scientific Research Publishing (SCIRP) is one of the largest Open Access journal publishers. It is currently publishing more than 200 open access, online, peer-reviewed journals covering a wide range of academic disciplines. SCIRP serves the worldwide academic communities and contributes to the progress and application of science with its publication.

Other selected journals from SCIRP are listed as below. Submit your manuscript to us via either submit@scirp.org or Online Submission Portal.
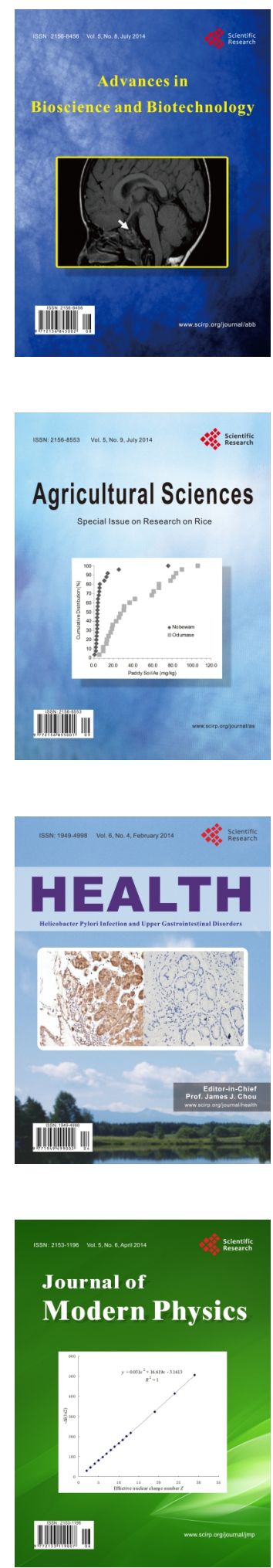
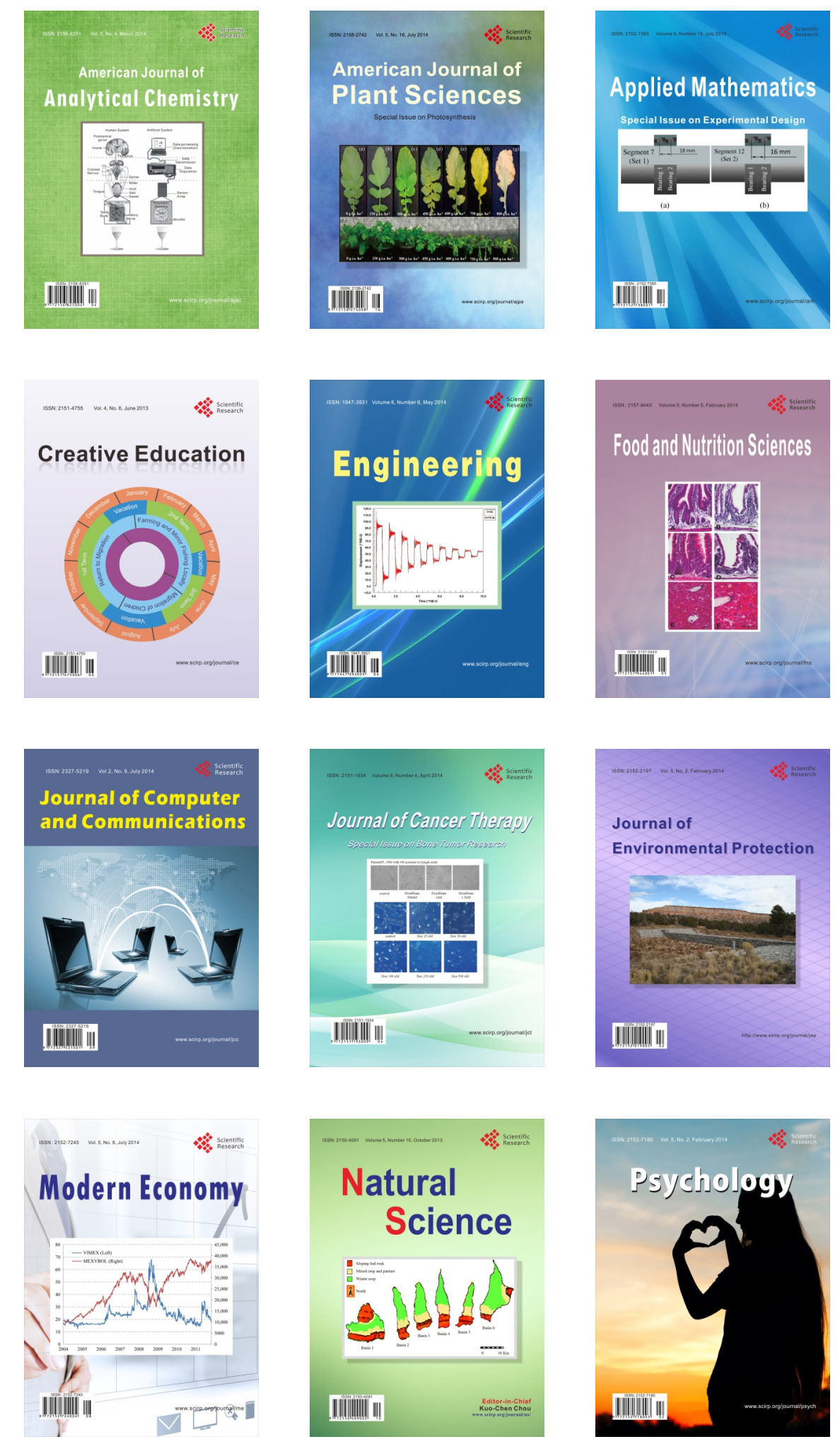